\title{
PKM PELATIHAN MICROSOFT OFFICE 2016 YANG EFEKTIF DAN EFISIEN PADA HIMPAUDI DI KECAMATAN BATAM KOTA
}

\author{
Amrizal \\ Universitas Putera Batam (UPB), Batam, Indonesia \\ e-mail: amrizal@puterabatam.ac.id \\ Tukino \\ Universitas Putera Batam (UPB), Batam, Indonesia \\ e-mail: tukino@puterabatam.ac.id \\ Rika Harman \\ Universitas Putera Batam (UPB), Batam, Indonesia \\ e-mail: rika@puterabatam.ac.id
}

\begin{abstract}
The development of soft skills at the Association of Early Childhood Educators and Education Personnel in Batam City District can be fulfilled through a Multimedia learning model based on Information and Communication Technology (ICT). The training for developing multimedia learning media based on Information and Communication Technology aims to provide skills in making interesting multimedia learning media in a relatively easy way. The method applied in this activity is the Method of Presentation, Demonstration and Practice. Presentation method is used for software introduction using Microsoft Powerpoint 2016. Demonstration method regarding program operation and Practice Method, namely making learning media directly by participants according to their respective subjects by utilizing these programs. The results of this study are: First, the training provides several materials related to efforts to improve the quality of learning by providing knowledge about the use of the Powerpoint Program to create interactive games as an attractive and interactive ICT-based multimedia learning media, Second, the material presented is acceptable, digestible, and well understood by the participants, Third, the activity went smoothly, on time and as expected.
\end{abstract}

Keywords-Multimedia Learning Model, Information and Communication Technology, Microsoft Powerpoint

\section{PENDAHULUAN}

Sebagai bentuk kerja sama dan bukti bahwa Universitas Putera Batam peduli pada lingkungan sekitarnya, Universitas mempunyai organisasi binaan dibawah lembaga penelitian pengadian pada masyarakat melalui perpanjangan tangan oleh dosen dalam bentuk pengabdian masyarakat. Maka pelatihan yang telah dilakukan sebelumnya pada anggota pendidik dan tenaga kependidikan anak usia dini di kecamatan Batam Kota harus dilanjutkan. Sebagai ketua tim pengabdi merasa perlu diadakan pelatihan lanjutan sebagai keberlanjutan dari pembinaan khusunya pelatihan yang dilakukan sebelumnya. Dimana pelatihan yang telah dilakukan sebelumnya beroreantasikan pada penguasaan Microsoft Office 2010 dalam hal ini penguasaan Microsoft Word, Micrososft Powerpoint dan Microsoft Paint 2010 dan untuk saat sekarang dilanjutkan dengan Microsoft office 2016 untuk materi pelatihan yang sama yaitu tentang penguasaan Microsoft Word, 
Powerpoint dan Paint. Pelatihan dirasa perlu karena sebelumnya peserta pelatihan telah mendapatkan pelatihan untuk materi yang sama dengan versi yang lama Microsoft Office 2010 dan sekarang adalah Microsoft Office 2016, disamping itu juga untuk melihat secara berkala mamfaat dari pelatihan yang telah diadakan sebelumnya.

Percepatan dan perluasan layanan Pendidikan Anak Usia Dini (PAUD) merupakan salah satu kebijakan strategis yang digulirkan kementerian pendidikan nasional. Sejalan dengan kebijakan tersebut, penambahan dan peningkatan kompetensi dan kapasitas pendidikan PAUD menjadi tuntutan yang tidak dapat diabaikan. Berbagai program pengembangan diri mulai dikembangkan dalam rangka menunjang kebijakan tersebut, misalnya pelatihan, magang, pendampingan dan sebagainya,tentu saja hal ini diarahkan kepada pendidik anak usia dini yang ada. Keterbatasan pemerintah dalam memberikan pelatihan dan pendampingan yang berjenjang serta berkelanjutan menjadi salah satu kendala pemerataan dan peningkatan kompetensi pendidik PAUD. Karenanya untuk mendukung program tersebut perlu harus diseimbangkan dengan dukungan aktif pemerintah pusat melalui dirjen pendidikan dasar, pemerintah daerah serta yang tidak kalah penting adalah dukungan dari masyarakat sekitar. Ketiga faktor ini harus sejalan dan saling bersinergi sehingga tujuan yang diinginkan tercapai. Tujuan-tujuan tersebut harus dituangkan dalam bentuk rencana dan strategistrategi matang sehingga mudah dalam menjalankan dan mencapainya (Beny et al, 2012).

Salah satu strategi peningkatan mutu pendidik PAUD yang telah diberlakukan selama ini adalah melalui pengembangan Gugus. Upaya peningkatan mutu pendidik seperti yang dipersyaratkan dalam Undang-Undang Nomor 14 Tahun 2005 tentang Dosen dan Pendidik, menjadikan Gugus sebagai pintu masuk pertama (starting gate) yang strategis. Hal ini didasari oleh dua pemikiran, pertama; Gugus merupakan wadah berkumpulnya para pendidik pada level bawah dan paling memungkinkan bagi para pendidik untuk dapat berinteraksi dan berdiskusi secara cepat dalam mencari solusi terhadap permasalahan keseharian yang dihadapi di sekolahnya. Kedua; Gugus dapat ditingkatkan peran dan fungsinya sebagai wahana pembinaan profesi bagi pendidik dan pengelola atau kepala lembaga PAUD oleh unsur dan instansi terkait. Merujuk pada Peraturan Presiden Nomor 24 Tahun 2016 tentang Kedudukan, Tugas, dan Fungsi Kementerian Negara serta Susunan Organisasi, Tugas, dan Fungsi Eselon I Kementerian Negara, dimana pembinaan PAUD Formal dan Nonformal ditangani oleh satu direktorat, maka perlu adanya perluasan manajemen Gugus Taman Kanak-Kanak menjadi Gugus PAUD. Pembinaan terhadap Gugus PAUD diharapkan dapat meningkatkan dan memperkuat mutu serta eksistensi pendidik PAUD yang akhirnya berdampak positif terhadap peningkatan layanan PAUD yang lebih baik (Beny et al, 2012).

UU No 20 Th 2003 tentang Sistem Pendidikan Nasional Pasal 35 ayat 1 menyatakan bahwa "Standar sarana dan prasarana pendidikan mencakup ruang belajar, tempat berolahraga, tempat beribadah, perpustakaan, laboratorium, bengkel kerja, tempat bermain, tempat berkreasi dan berekreasi, dan sumber belajar lain yang diperlukan untuk menunjang proses pembelajaran, termasuk penggunaan teknologi informasi dan komunikasi". Lebih lanjut, dalam Peraturan Pemerintah Nomor 19 Tahun 2005 tentang Standar Nasional Pendidikan diperjelas bahwa yang dimaksud dengan standar sarana dan prasarana adalah 
kriteria minimal tentang sarana dan prasarana sebagaimana termuat dalam undang-undang di atas. Standar tersebut dikembangkan oleh Badan Standar Nasional Pendidikan (BSNP) dan ditetapkan dengan Peraturan Menteri. Dalam Peraturan Menteri No 24 Tahun 2007 tentang Standar Sarana dan Prasarana dirinci sarana prasarana yang dibutuhkan oleh satuan pendidikan, seperti laboratorium komputer dan kelengkapannya. Dalam Peraturan Menteri tersebut yang dimaksud dengan teknologi informasi dan komunikasi (TIK) adalah satuan perangkat keras dan lunak yang berkaitan dengan akses dan pengelolaan informasi dan komunikasi untuk mendukung pembelajaran. Sejak tahun 2005 pemerintah juga meluncurkan program pengembangan Rintisan Sekolah Bertaraf Internasional (RSBI) yang didalamnya menaruh perhatian yang tinggi terhadap penggunaan teknologi. Salah satu kompetensi yang harus dimiliki oleh guru yang mengajar di RSBI adalah mampu menggunakan TIK dalam proses pembelajaran, lihat Panduan Penyelenggaraan Program R-SMA-BI (2009) dan Panduan Pelaksanaan R-SMP-BI (2008). Hal-hal di atas menunjukkan bahwa pemerintah menyadari akan pentingnya pemanfaatan TIK sebagai media dalam proses pembelajaran (Beny et al, 2012).

Teknologi informasi dan komunikasi berkembang dengan pesat yang dipicu oleh temuan dalam bidang rekayasa material mikroelektronika. Perkembangan ini berpengaruh besar terhadap berbagai aspek kehidupan, bahkan perilaku dan aktivitas manusia kini banyak tergantung kepada teknologi informasi dan komunikasi. Mata pelajaran Teknologi Informasi dan Komunikasi dimaksudkan untuk mempersiapkan peserta didik agar mampu mengantisipasi pesatnya perkembangan tersebut. Mata pelajaran ini perlu diperkenalkan, dipraktikkan dan dikuasai peserta didik sedini mungkin agar mereka memiliki bekal untuk menyesuaikan diri dalam kehidupan global yang ditandai dengan perubahan yang sangat cepat. Untuk menghadapi perubahan tersebut diperlukan kemampuan dan kemauan belajar sepanjang hayat dengan cepat dan cerdas. Hasil-hasil teknologi informasi dan komunikasi banyak membantu manusia untuk dapat belajar secara cepat (Beny et al, 2012).

Dengan demikian selain sebagai bagian dari kehidupan sehari-hari, teknologi informasi dan komunikasi dapat dimanfaatkan untuk merevitalisasi proses belajar yang pada akhirnya dapat mengadaptasikan peserta didik dengan lingkungan dan dunia kerja. Fenomena seperti ini sudah barang tentu merupakan hal yang sangat menguntungkan, dan harus dimanfaatkan dengan sebaik-baiknya guna mendukung segala tugas dan kewajibannya sehari-hari. Contoh nyata dari pemanfaatan perkembangan teknologi ini adalah dengan pembuatan media pembelajaran yang memanfaatkan program aplikasi Microsoft Office 2016. Dalam pelatihan tersebut, para peserta dilatih bagaimana cara menggunakan berbagai program aplikasi, baik yang berbasis pengolah kata (Microsoft Word 2016), program aplikasi multi media (Microsoft Powerpoint 2016). Dan aplikasi yang mendukung kreatifitas pada Microsoft Paint 2016

Untuk itu teknologi informasi perlu diperkenalkan kepada anak-anak sejak usia dini. Salah satu upaya yang perlu dilakukan untuk menggapai pengusaan teknologi dimasa depan adalah melalui pengenalan teknologi informasi kepada anak-anak sejak usia dini. Dalam perkembangan Dan kehidupannya, setiap murid perlu menguasai berbagai kemampuan atau kompetensi. Dengan kemampuan atau kompetensi itulah murid hidup Dan berkembang. Umumnya kemampuan atau kompetensi tertentu harus dipelajari. Dengan perkataan lain kepemilikan 
kemampuan atau kompetensi tertentu oleh murid harus melalui proses belajar. Dalam rangka ini, sekolah harus bisa memenuhi kebutuhan belajar murid. Ada berbagai macam cara dilakukan oleh Anggota pendidik dan tenaga kependidikan anak usia dini di kecamatan Batam Kota untuk memenuhi kebutuhan belajar murid, diantaranya adalah dengan meningkatkan sarana Dan prasarana pendidikan. Untuk mengikuti perkembangan zaman Dan juga tuntutan tujuan pembelajaran, Anggota perhimpunan pendidik dan tenaga kependidikan anak usia dini di kecamatan Batam Kota dituntut kreatif dalam meningkatkan sarana proses pembelajaran salah satunya adalah penggunaan Microsoft Word 2016, Microsoft Powerpoint 2016, dan Microsoft Paint 2016.

Melalui Microsoft Word 2016, Microsoft Powerpoint 2016, dan Microsoft Paint 2016 yang ditayangkan tidak saja berupa tulisan-tulisan yang mungkin sangat membosankan, tetapi dapat juga ditampilkan gambar-gambar dan suarasuara menarik yang tersedia dalam program MS Powerpoint. Anggota pendidik dan tenaga kependidikan anak usia dini di kecamatan Batam Kota PAUD dapat pula memasukkan gambar-gambar di luar fasilitas Powerpoint, sehingga sasaran yang akan dicapai menjadi lebih optimal. Gambar-gambar yang disajikan melalui program Powerpoint tidak statis seperti yang terdapat pada Over Head Projector $(O H P)$. Anggota pendidik dan tenaga kependidikan anak usia dini di kecamatan Batam Kota dapat memasukkan gambar-gambar yang bergerak, bahkan konselor bisa melakukan insert gambar-gambar yang ada di sebuah film. Pada prinsipnya program ini terdiri dari beberapa unsur rupa, Dan pengontrolan operasionalnya. Unsur rupa yang dimaksud, terdiri dari slide, teks, gambar Dan bidang-bidang warna yang dapat dikombinasikan dengan latar belakang yang telah tersedia. Unsur rupa tersebut dapat kita buat tanpa gerak, atau dibuat dengan gerakan tertentu sesuai keinginan kita (Beny et al, 2012).

Microsoft Word 2016, Microsoft Powerpoint 2016, dan Microsoft Paint 2016 diperkenalkan kepada anggota perhimpunan pendidik dan tenaga kependidikan anak usia dini di kecamatan Batam Kota dimaksudkan sebagai salah satu upaya untuk mengenalkan teknologi komputer kepada anak usia dini. Jadi untuk memperkenalkan teknologi tesebut Anggota perhimpunan pendidik dan tenaga kependidikan anak usia dini di kecamatan Batam Kota selain perlu menguasai pengtahuan tentang teknologi komputer juga perlu menguasai metode Dan strategi pengajaran termasuk alat bantu pengajaran yang kreatif, interaktif serta mendidik. Microsoft Word 2016, Microsoft Powerpoint 2016, dan Microsoft Paint 2016 merupakan alat bantu pengajaran yang sederhana, mudah dipahami tetapi mempunyai nilai mamfaat yang tinggi karena murid merasa tidak bosan dengan penampilan gambar, warna-warni yang menarik Dan kelihatan seperti nyata sehingga bagi anak usia dini tampilan pada Microsoft Word 2016, Microsoft Powerpoint 2016, dan Microsoft Paint 2016 merupakan suatu hal yang mempunyai daya tarik tersediri.

Penggunaan komputer oleh Anggota pendidik dan tenaga kependidikan anak usia dini di kecamatan Batam Kota sebagai salah satu produk teknologi informasi Dan komunikasi dapat mendukung tercapainya tujuan pembelajaran. Untuk itu, seorang anggota perhimpunan pendidik dan tenaga kependidikan anak usia dini di kecamatan Batam Kota dituntut untuk kreatif guna meningkatkan aktivitas murid Dan meningkatkan mutu pembelajaran. Untuk mencapai tujuan tersebut, Anggota perhimpunan pendidik dan tenaga kependidikan anak usia dini seyogyanya mulai menyadari pentingnya aspek teknologi untuk menunjang proses 
pembelajaran, salah satunya adalah bahan sajian yang menggunakan komputer. Program pembelajaran yang berbasis komputer efektif dalam mempertahankan minat peserta didik, karena mampu memadukan berbagai jenis media, gambar bergerak selayaknya informasi yang tercetak. Media pembelajaran berbasis komputer tersebut khususnya adalah piranti lunak presentasi Microsoft Word 2016, Microsoft Powerpoint 20166, dan Microsoft Paint 2016.

Aplikasi Microsoft Office atau yang lebih dikenal sebagai Office, tentu saja hampir semua orang mengenalnya, terutama bagi mereka yang biasa berurusan dengan pembuatan tulisan atau laporan. Tak terkecuali Anggota perhimpunan pendidik dan tenaga kependidikan anak usia dini. Bagi Anggota Organisasi PAUD, Microsoft Office 2016 tentu saja sangat membantu kegiatannya dalam mempersiapkan pembelajaran, melaksanakan kegiatan pembelajaran, sampai tahap evaluasi dan pelaporan kegiatan yang dilakukan. Tetapi Microsoft Office 2016 akan sangat membantu bila fitur-fitur yang dimilikinya dapat digunakan secara optimal. Untuk itu, seorang Anggota perhimpunan pendidik dan tenaga kependidikan anak usia dini sudah sepantasnya selalu meningkatkan kemampuannya dalam mengoptimalkan fitur yang dimiliki oleh Microsoft Office 2016.

Microsoft Office 2016 yang diperdalam kali ini adalah Microsoft Word 2016 dan Microsoft Powerpoint 2016. Microsoft Word 2016 difokuskan pada penggunaan Microsoft Word 2016 untuk pengetikan naskah yang memuat objek dan simbol matematika, dan pemanfaatan Microsoft Word 2016 untuk penulisan karya tulis ilmiah yang meliputi menu Page Layout dan menu Reference. Pada menu Page Layout membahas penomoran halaman yang berbeda, dan orientasi halaman yang berbeda dalam satu dokumen karya tulis. Menu Reference membahas gaya (Style) sitasi (kutipan) yang digunakan dalam dokumen, cara memasukkan kutipan, dan cara membuat daftar isi serta daftar pustaka secara otomatis. Sedang Microsoft Powerpoint 2016 difokuskan pada penggunaan animasi yang tepat sesuai konteks dalam pembuatan alat bantu pembelajaran matematika. Selain itu, materi Microsoft Powerpoint 2016 juga membahas bagaimana cara menyisipkan objek yang berupa picture, shape, word art, audio dan video serta membuat hyperlink dalam satu dokumen. Yang tak kalah pentingnya dalam pembuatan alat bantu pembelajaran dengan menggunakan Microsoft Powerpoint 2016 adalah pemilihan animasi serta timing yang tepat untuk tiap objek yang disisipkan, agar konsep yang disampaikan dapat dengan mudah dipahami oleh peserta didik (Beny et al, 2012).

Menyimak materi yang disampaikan, ini sangat erat kaitannya dengan dengan keseharian seorang Anggota perhimpunan pendidik dan tenaga kependidikan anak usia dini. Seperti kita ketahui bahwa tugas seorang Guru PAUD bukan hanya hanya mendidik, melatih, dan mengajar. Akan tetapi selain itu, Guru PAUD dituntut pula untuk selalu mengembangkan kemampuan dan kompetensinya melalui suatu kegiatan yang dikenal dengan pengabdian kepada masyarakat. Salah satu unsur dalam PKB adalah membuat karya tulis ilmiah. Tentu saja, kemampuan memanfaatkan fitur yang dimiliki Microsoft Word 2016 dan Microsoft Powerpoint 2016 akan berpengaruh dalam pembuatan rencana kegiatan dan pelaporan hasil kegiatan ilmiah yang dilakukan oleh Anggota guru PAUD. Microsoft Powerpoint 2016 sangat membantu dalam pengembangan alat bantu pembelajaran agar konsep yang disampaikan mudah dipahami oleh peserta didik, dan Microsoft Word 2016 sangat membantu dalam pelaporan kegiatan 
pengabdian kepada masyarakat yang akan dan telah dilakukan Anggota perhimpunan pendidik dan tenaga kependidikan anak usia dini. Microsoft Paint 2016 adalah sebuah aplikasi (perangkat lunak) yang merupakan bagian dari paket Software Microsoft Office 2016. Perangkat lunak ini berjenis yang mampu membangun kreativitas mendisain, menggambar dan mewarnai obyek.

Seperti telah dibahas di atas, bahwa perkembangan $\mathrm{TI}$ dewasa ini telah berimbas pada dunia pendidikan, dengan ditandai oleh munculnya berbagai inovasi dan kreasi dalam proses penyampaian bahan ajar kepada peserta didik Sebagaimana kita ketahui, bahwa dalam proses pendidikan terdapat 3 proses inti pendidikan (Core processes), yaitu; Pengajaran (Teaching), Penelitian (Research), dan Pelayanan (Services), dimana ketiganya menjadi sumber akses bagi enggunaan dan pemanfaatan TI. Ada beberapa konsep yang melatar belakangi penggunanaan TI untuk kegiatan pendidikan, dan beberapa diantara sudah banyak diterapkan di lembaga pendidikan baik tingkat dasar maupun tingkat menengah, apalagi di perguruan tinggi. Penggunanaan teknologi ini telah berdampak langsung dan tidak langsung terhadap cara penyelenggaraan pendidikan yang mengarah pada peningkatan mutu sumberdaya manusia.Kegiatan Pengabdian ini yang berjudul "Pelatihan Microsoft Office 2016 yang efektif dan efisien pada perhimpunan pendidik dan tenaga kependidikan anak usia dini di kecamatan Batam Kota dalam upaya meningkatkan profesionalisme tenaga pengajar PAUD sebagai tenaga pendidik yang berkualitas" Pengabdian ini diselenggarakan oleh Dosen Universitas Putera Batam Tahun 2017. Tentunya Kegiatan Pengabdian ini memerlukan dukungan Dan bantuan dari segenap pihak, baik sivitas akademika Fakultas Teknik Universitas Putera Batam maupun pihak lain atas dasar kebersamaan. Dukungan moral Dan materi akan sangat membantu program ini, yang dengan semangat kemanusiaan Dan pengabdian masyarakat mampu menolong mereka yang membutuhkan.

\section{PERMASALAHAN MITRA}

Berkembangnya lembaga Pendidikan Anak Usia Dini dalam berbagai bentuk layanan Pendidikan Anak Usia Dini seperti : TK, KB, TPA, SPS menunjukkan semakin meningkatnya kesadaran masyarakat tentang pentingnya pendidikan yang sesuai tahap perkembangan sejak usia dini. Peningkatan jumlah lembaga layanan Pendidikan Anak Usia Dini diikuti dengan kebutuhan akan penambahan jumlah pendidik PAUD. Kebutuhan akan tenaga pendidik tidak hanya terkait dengan jumlah tetapi juga terkait dengan mutu. Pembinaan pendidik dalam kaitannya dengan peningkatan kemampuan pendidik dalam memberikan layanan PAUD yang sesuai dengan kebutuhan pertumbuhan dan perkembangan anak merupakan langkah yang ditempuh Direktorat Pembinaan Pendidikan Anak Usia Dini. Pembinaan dilakukan melalui berbagai strategi dan program kegiatan praktis. Satu diantara pola pembinaan pendidik dan tenaga kependidikan PAUD dilakukan melalui Gugus Pendidikan Anak Usia Dini (Gugus PAUD).

Gugus Pendidikan Anak Usia Dini merupakan wadah strategi yang dibangun dari, oleh dan untuk anggota perhimpunan pendidik dan tenaga kependidikan anak usia dini kecamatan Batam Kota Kota Batam, program, bentuk kegiatan direncanakan, dikembangkan, dan dilaksanakan untuk memenuhi kebutuhan peningkatan profesi pendidik seuai dengan kebutuhan anggota. Dalam rangka mendorong lembaga-lembaga PAUD membentuk Gugus PAUD, maka disusun Pedoman Pembinaan Gugus Pendidikan Anak Usia Dini. Pedoman ini memuat acuan tentang latar belakang, dasar hukum, tujuan pedoman dan pengertian- 
pengertian yang dirangkum dalam pendahuluan. Selanjutnya dipaparkan struktur dan mekanisme kerja Gugus PAUD yang memuat fungsi, tata cara pembentukan gugus, mekanisme dan program kerja gugus. Dalam pedoman ini juga dipaparkan pusat kegiatan gugus, yakni wadah koordinasi antar gugus, mengingat demikian banyaknya jumlah gugus dalam satu kecamatan. Keberadaan PKG menjadi basecamp informasi yang terkait dengan upaya pembinaan dan peningkatan layanan PAUD untuk ditindaklanjuti ke gugus-gugus PAUD. Mekanisme tersebut merupakan pola pembinaan gugus PAUD yang dilakukan secara berjenjang. Semoga pedoman ini bermanfaat sebagaimana yang diharapkan.

Berdasarkan Latar Belakang Pengabdian Dan Gambaran Umum Obyek Pengabdian, maka penulis mengambil beberapa rumusan masalah, diantaranya:

a) Bagaimana menerapkan Microsoft Word 2016, Microsoft Powerpoint 2016 dan Microsoft Paint 2016 dalam proses pembelajaran yang aktif, interaktif serta menarik sehingga murid akan lebih memperhatikan selama proses pembelajaran.

b) Bagaimana Murid akan lebih mudah mengingat materi yang diberikan guru PAUD, karena pembelajaran tidak hanya dirancang dalam kontek bercerita saja tetapi dilengkapi juga dengan penyajian gambar sehingga cerita yang disampaikan dapat dilihat langsung dalam bentuk animasi atau gambarnya, serta penyajian materi juga lebih mudah karena sudah diatur menggunakan slide-slide.

c) Bagaimana membuat sebuah proses pembelajaran yang tidak akan membosankan tetapi lebih interaktif melalui penampilan gambar yang bergerak (animasi), penampilan warna yang lebih baik dan menarik, serta bentuk contoh pembelajaran yang lebih nyata seperti hewan dan tumbuh-tumbuhan sehingga siswa lebih merasakan dengan baik apa yang disampaikan.

d) Kemudahan bagi anggota pendidik dan tenaga kependidikan anak usia dini di kecamatan Batam Kota itu sendiri dalam penyelesaian tugastugas pribadi maupun tugas-tugas sekolah yang berkaitan dengan pelaporan data nilai, pelaporan pengajaran serta sertifikasi guru dan lain sebagainya

Adapun sasaran dari pengabdian masyarakat bagi anggota perhimpunan pendidik dan tenaga kependidikan anak usia dini kecamatan Batam Kota di Kota Batam, ini adalah:

a) Terciptanya daerah binaan dari Universitas Putera Batam terhadap anggota pendidik dan tenaga kependidikan anak usia dini di kecamatan Batam Kota pada umumnya dan masing-masing pribadi dari guru PAUD pada khsuusnya.

b) Berkembangnya daerah kemitraan dari Universitas Putera Batam sendiri dengan pusat kerja anggota pendidik dan tenaga kependidikan anak usia dini di kecamatan Batam Kota dalam hal pengembangan ilmu Dan teknologi khususnya Microsoft Word 2016, Microsoft Powerpoint 2016 dan Microsoft Paint 2016.

c) Meningkatnya pemahaman Dan pengetahuan dari guru PAUD Kecamatan Batam Kota tentang pentingnya pemamfaatan Microsoft Word 2016, Microsoft Powerpoint 2016 dan Microsoft Paint 2016 didalam proses pembelajaran serta mamfaat lain untuk kepentingan profesional dari anggota pendidik dan tenaga kependidikan anak usia dini di kecamatan Batam Kota sendiri. 


\section{METODE}

Untuk metode pelaksanaan adalah hal yang sangat penting karena menyangkut dari prosedure pelaksanaan pembinaan. Untuk metode pelaksanaan kegiatan pembinaan sendiri ada beberapa hal yang perlu dilakukan diantaranya adalah sebagai berikut:

1. Melakukan perkenalan dari masing tim pembinaan dan dilanjutkan dengan melakukan perkenalan dalam hal ini pendataan peserta pembinaan pada anggota perhimpunan pendidik dan tenaga kependidikan anak usia dini kecamatan Batam Kota yang hadir ditempat acara.

2. Dilakukan pemaparan materi oleh tim dosen dilanjutkan dengan istirahat sambil ramah tamah dengan peserta pembinaan pada Anggota perhimpunan pendidik dan tenaga kependidikan anak usia dini kecamatan Batam Kota.

3. Melakukan diskusi atau memberikan kesempatan untuk bertanya dari peserta pembinaan seputar materi yang telah disampaikan apakah peserta pembinaan mengalami kesulitan dalam menerima pemaparan materi dari masing-masing pemakalah.

4. Melakukan evaluasi timbal balik atas hasil yang diharapkan dalam hal ini adalah terciptanya modul pembelajaran dan teknik pembelajaran pengenalan teknologi informasi kepada anak didik PAUD dan Taman kanak-kanak.

5. Mengadakan pelatihan 3 kali setiap hari Sabtu mulai dari Hari Sabtu Tanggal 11, 18 dan 25 Maret 2017 secara berkala dan sekaligus melakukan penilaian atas kemajuan perkembangan dari guru PAUD kelompok kerja Batam Kota.

\section{HASIL DAN PEMBAHASAN}

\section{A. Hasil}

Berdasarkan pelatihan yang telah dilakukan pada pada anggota perhimpunan pendidik dan tenaga kependidikan anak usia dini kecamatan Batam Kota, diharapakan dapat memberikan dampak yang positif kepada para peserta itu sendiri dan juga kepada tim dosen (pengabdi) yang melakukan pelatihan, atau secara rinci hasil yang ingin dicapai dari pelaksanaan pelatihan tersebut dapat diuraikan antara lain adalah sebagai berikut:

a) Tercipta dan bertambahnya daerah binaan baru dari Universitas Putera Batam dalam hal ini adalah terciptanya daerah binaan dengan perhimpunan pendidik dan tenaga kependidikan anak usia dini kecamatan Batam Kotauntuk bidang ilmu, teknologi dan pengetahuan.

b) Terjalinnya kerjasama antara Universistas Putera Batam dengan masyarakat luar dalam hal ini adalah dengan anggota perhimpunan pendidik dan tenaga kependidikan anak usia dini kecamatan Batam Kota.

c) Dapat menambah wawasan tersendiri dari saya pribadi dan rekan tim dosen pengabdi yang lain dalam hal pemahaman tentang guru dari anak usia dini (AUD) dan kendala yang mereka hadapi dalam mengajar sekaligus mengerjakan tugas administrasi sekolah.

d) Menambah wawasan dan pengetahuan bagi peserta pelatihan itu sendiri perhimpunan pendidik dan tenaga kependidikan anak usia dini kecamatan Batam Kota dalam bidang komputer khususnya Microsoft 
Office 2016 berupa Microsoft Word 2016, Microsoft Powerpoint 2016 dan Microsoft Powerpaintt 2016.

e) Dapat mengembangkan serta berbagi ilmu pengetahuan kesetiap lapisan masyarakat yang ada, termasuk dalam hal ini adalah pada anggota perhimpunan pendidik dan tenaga kependidikan anak usia dini kecamatan Batam Kota.

Faktor yang mendukung terlaksananya pengabdian masyarakat pada anggota perhimpunan pendidik dan tenaga kependidikan anak usia dini kecamatan Batam Kota adalah:

a) Sambutan positif dari ketua anggota perhimpunan pendidik dan tenaga kependidikan anak usia dini kecamatan Batam Kota, dalam hal ini terlihat dari segi waktu seperti banyaknya waktu yang diberikan kepada tim pengabdi mulai diadakan waktu pelatihan awal sampai kepada proses keberlanjutannya dari pembinaan ini nantinya.

b) Besarnya minat dan antusiasme peserta pelatihan yaitu guru anak usia dini (AUD) hal ini terbukti dengan banyaknya peserta yang hadir, banyaknya pertanyaan dari para peserta yang berhubungan dengan materi yang disampaikan.

c) Pelatihan diadakan dalam ruangan kelas belajar yang rapi dan bersih serta telah disediakan LCD proyektor sehingga dalam penyampain materi lebih jelas, cepat dan semua peserta dapat mengikuti dengan seksama.

d) Para peserta sudah siap dengan diadakannya pelatihan ini, hal tersebut tampak jelas dari peserta yang membawa laptop sendiri, jadi para tim dosen tidak terlalu sulit dalam memberikan dan menjelaskan materi pelatihan.

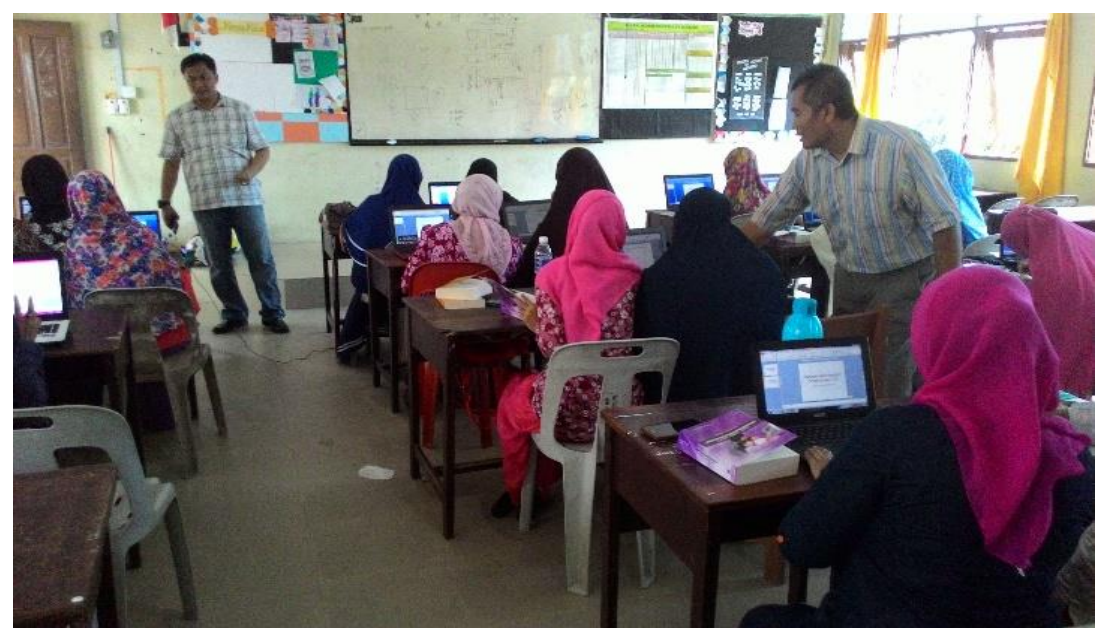

Gambar 1. Kegiatan Pengabdian hari pertama

\section{B. Pembahasan}

Para peserta kegiatan hadir sesuai dengan waktunya walaupun ada beberapa orang yang datang belakangan, begitu juga dengan kami sebagai tim pengabdi datang tepat waktu dan pemberian materi dari masing-masing dosen juga telah sesuai dengan waktu yang tertera pada pada tabel susunan acara yaitu satu jam untuk masing-masing dosennya. Teknis pelaksanaan pelatihannya pada saat rekan pengabdi memaparkan materi, para peserta pelatihan akan langsung mempraktekkan dibelakang dilaptop masing-masing secara langsung, jika ada 
permasalahan maka dua pengabdi yang ada dibelakang akan segera membantu sehingga proses pelatihan dapat berjalan dengan cepat. Disamping materi yang ada didepan (Microsoft Powerpoint) para peserta pelatihan juga dilengkapi dengan diktat dalam bentuk Microsoft Word sehingga mereka dapat mempraktekkan sendiri dan mempelajari secara mandiri dirumah.

Untuk lebih jelasnya pelaksanaan kegiatan tersebut dapat pengabdi tampilkan dalam bentuk sebuah tabel (tabel pelaksanan kegiatan) yang antara lain seperti pada tabel dibawah ini:

Tabel 1. Pelaksanaan Kegiatan

\begin{tabular}{|c|c|c|c|}
\hline NO & Waktu & Kegiatan & Nara Sumber \\
\hline 1 & $08 .^{00}-08 .^{30}$ & Kumpul Panitia (Dosen) & \\
\hline 2 & $08 .^{30}-08 .^{45}$ & Sambutan tuan rumah & Ibu Patmawati \\
\hline 3 & $08.45-09.00$ & $\begin{array}{l}\text { Sambutan dari Ketua } \\
\text { Pengabdian Masyarakat }\end{array}$ & Amrizal, S.Kom., M.SI \\
\hline \multirow[t]{4}{*}{4} & $09.00-12 .^{00}$ & Acara Inti & \\
\hline & \multicolumn{2}{|c|}{$\begin{array}{l}\text { 1. Penyampaian Materi Microsoft paint } \\
\text { dan Microsoft Powerpoint beserta } \\
\text { latihan }(09.00-10.30)\end{array}$} & $\begin{array}{l}\text { Amrizal, S.Kom., M.SI \& } \\
\text { Tukino, S.Kom., M.SI }\end{array}$ \\
\hline & \multicolumn{2}{|c|}{$\begin{array}{l}\text { 2. Penyampaian Materi Microsoft Word } \\
\left(10 . .^{30}-12 .{ }^{00}\right)\end{array}$} & Rika Harman, S.Kom., M.SI \\
\hline & \multicolumn{2}{|c|}{$\begin{array}{l}\text { 3. Ramah Tamah dan Persiapan } \\
\text { Pulang }\left(12 .^{00}-13 . .^{.0}\right)\end{array}$} & \\
\hline 5 & \multicolumn{2}{|c|}{ Penutupan Oleh Tuan Rumah } & Ibu Patmawati \\
\hline
\end{tabular}

Sumber: Data Lapangan Pengabdian Penulis (2017)

Keterangan:

Dari tabel 1 diatas dapat dijelaskan bahwa pelaksanaan kegiatan pengabdian telah berlangsung sesuai dengan susunan acara yang direncanakan diawal. Tahap-tahap demi tahap untuk masing pengabdi dalam memberikan pemaparan materi berjalan dengan baik. Jadi dapat dikatakan proses pengabdian (pelatihan) kepada anggota perhimpunan pendidik dan tenaga kependidikan anak usia dini kecamatan Batam Kotaberjalan dengan lancar.

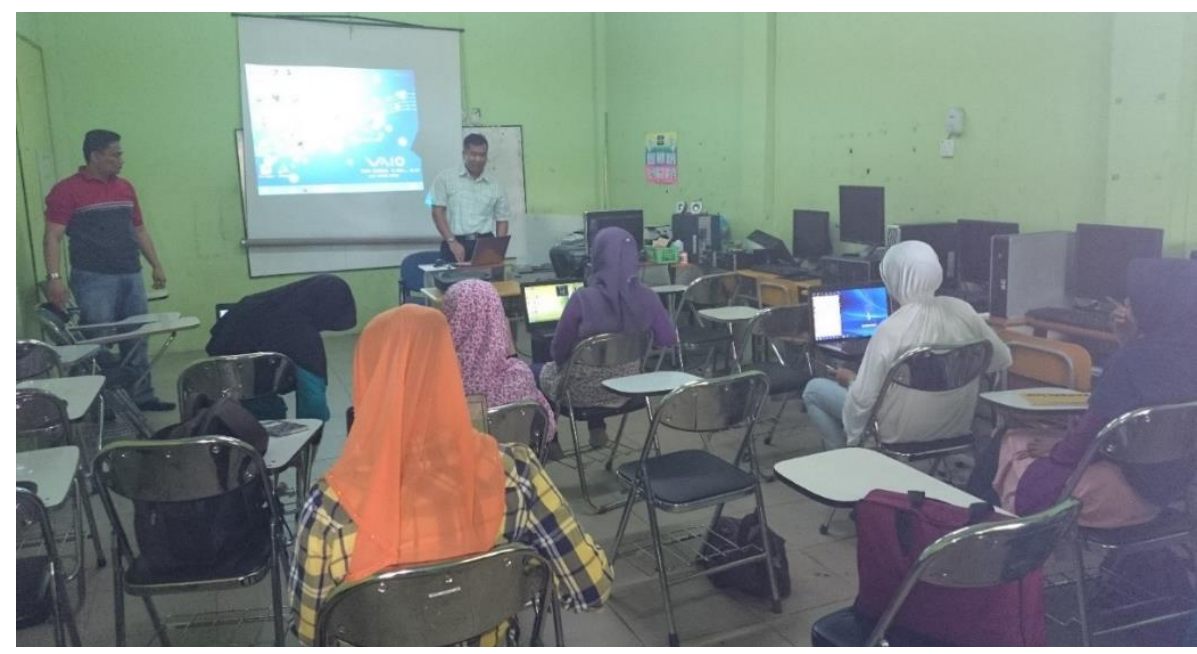

Gambar 2. Kegiatan Pengabdian hari kedua 
Selanjutnya dapat pengabdi jelaskan juga bahwa untuk masing-masing pengabdi mempunyai materi dan topik yang berbeda antara pengabdi satu dengan yang lainya, berikut adalah tabel untuk nama pengabdi lengkap dengan topiknya diantaranya seperti pada tabel dibawah ini

Tabel 2: Nama Pengabdi dan Topiknya

\begin{tabular}{|l|l|l|}
\hline \multicolumn{1}{|c|}{ Nama Dosen } & & \multicolumn{1}{c|}{ Topik } \\
\hline Amrizal, S.Kom., M.SI & $:$ & Pelatihan Microsoft Paint \\
\hline Tukino, S.Kom., M.SI & & Pelatihan Microsoft Powerpoint 2016 \\
\hline Rika Harman, S.Kom., M.SI & $:$ & Pelatihan Microsoft Word 2016 \\
\hline
\end{tabular}

\section{Keterangan:}

Berdasarkan tabel diatas dapat dijelaskan bahwa saya sebagai pengabdi bertugas memberikan materi disesi ketiga $09 .{ }^{00}-10^{\cdot 30}$ dengan topik Microsoft Paint. Setelah dua pengabdi sebelumnya.

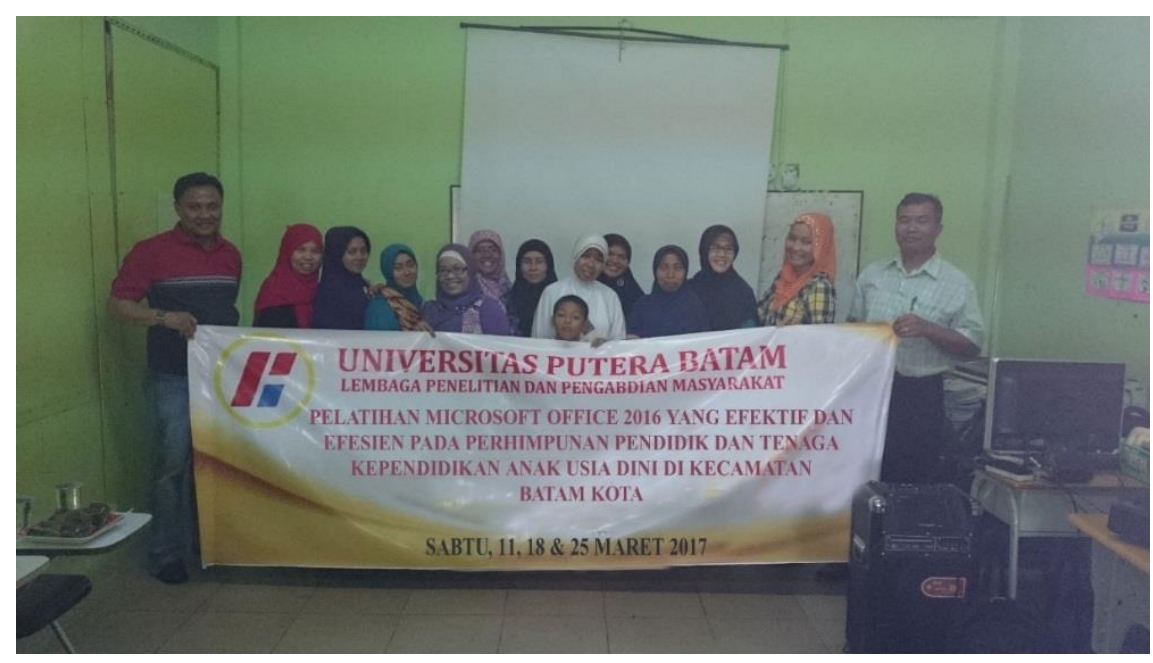

Gambar 3. Foto bersama peserta Pengabdian

\section{KESIMPULAN}

Dari beberapa kegiatan yang telah kami laksanakan, tim pengabdi dapat memberikan beberapa kesimpulan:

a) Pengetahuan dan penguasaan Micrososft Office khususnya Microsoft Word 2016 untuk saat sekarang mutlak harus dikuasai secara baik tidak terkecuali oleh para guru Anak Usia Dini (AUD), karena dengan pemamfaatan Microsoft Office proses pembelajaran akan lebih baik dan juga dapat membantu menyelesaikan tugas-tugas adiministrasi sekolah.

b) Soeorang guru pada anak usia dini (PAUD) harus dapat menyajikan materi pembelajaran yang interaktif sehingga anak didik walaupun anak usia dini lebih tertarik dengan apa yang disampaikan dan mereka dapat mendengar dan melihatnya secara langsung.

c) Seorang guru pada anak usia dini (PAUD) harus mampu membuat materi pembelajaran yang mampu diingat lebih lama oleh peserta didiknya hal ini tentu tidak bisa hanya dengan bercerita saja tapi harus disertai dengan gambar-gambar pendukung, model seperti ini akan dapat membantu daya ingat peserta didik menjadi lebih lama. 
d) Seorang guru pada anak usia dini (PAUD) dituntut juga membuat materi pembelajaran yang tidak membosankan, harus lebih kreatif, inovatif, jadi disamping mengandalkan alat peraga seorang guru juga dituntut lebih menguasai Powerpoint sehingga dapat menyajikan gambar-gambar peraga yang lebih banyak dan menarik secara langsung didepan kelas.

\section{SARAN}

Berdasarkan kesimpulan kegiatan di atas, maka disarankan HIMPAUDI Di Kecamatan Batam Kota, antara lain adalah:

1) Kegiatan ini dapat dilangsungkan di HIMPAUDI Di Kecamatan Batam Kota.

2) Dapat dilakukan pengabdian lebih lanjut dengan materi yang lebih advance.

3) Jangka waktu pelaksanaan agar dapat diperpanjang mengingat sulitnya transfer ketrampilan dalam waktu yang relatif sempit.

4) Perlu dana yang lebih besar agar hasilnya lebih optimal.

\section{UCAPAN TERIMA KASIH}

Terima kasih kepada LPPM Universitas Putera Batam sebagai pemberi dana dalam pengabdian ini sehingga pengabdian ini dapat terlaksana dengan baik. Terima kasih kepada HIMPAUDI Di Kecamatan Batam Kota yang menjadi objek pengabdian penulis.

\section{DAFTAR PUSTAKA}

http://pkk.batamkota.go.id/?p=8398 di akses Tanggal 10 Nopember 2013, Jam 10:39

Beny A. P., Setiawan, D., Sutarto, A. \& Novita, D. (2012). Komputer Dalam Kegiatan Pengembangan Anak Usia Dini Edisi 1. Tangerang Selatan: Universitas Terbuka. 